\title{
EXPLOITING HYPERTEXT'S POTENTIAL FOR TEACHING GENDER STUDIES
}

\author{
Maya Zalbidea Paniagua*
}

\begin{abstract}
The aim of this article is to show what feminist electronic literature can contribute to the study of gender theories and feminist literature. The study of feminist hypertext fictions and the use of hypertext as a teaching tool are facilitated by the intrinsic characteristics of the electronic medium, complementing the electronic medium and providing alternative possibilities in the learning process: collaborative authorship, multivocality, textual openness, non-hierarchical and rhizomatic structures, neo-kathartic effects and open publishing. Teaching feminist electronic literature using the hypertext offers the possibility of updating and discussing gender through a medium that permits rearranging the hypertext, better organized analyses of intertextuality and fostering the study through association and connections, which is the way the human brain works. The teaching method proposed pursues the objective of studying narratives about gender taking advantage of the new technologies without losing dialogues in class as intuitive learning process.
\end{abstract}

KEY WORDS: Teaching. Gender. Hypertext. Electronic literature. Carolyn Guyer. Francesca da Rimini. Susan Gibb.

\section{Introduction}

Blended learning combines face to face classroom methods with computermediated activities, this learning approach permits a new way of teaching in which the study plans can be updated corresponding to present day students needs. Teaching through the use of hypertexts permits the instructor and students to complement classroom attendance with a digital environment. The qualities of a hypertext offer an infinite number of advantages which could not exist in a printed format: fast and efficient updates, the possibility of sharing information with others in a website dedicated to a specific course, creating original hypertext fictions in a creative writing course, etc. Nowadays, some of the areas of research on literature and cultural studies in which students are more interested are actually related to minorities issues: ethnic groups, postcolonial studies and gender studies. Most researches on humanities at this moment are dealing with postcolonial studies, ecocriticism, the digitalization of literature and media studies. After centuries of academic studies based on classic literary works of Western upper or middle class

\footnotetext{
*Ph. D. English Studies; Associate Professor; Camilo José Cela University mayazalbidea@gmail.com
}

Texto Digital, Florianópolis, v. 8, n. 1, p. 104-126, jan./jul. 2012. ISSNe: 1807-9288 
white men and women, present day researchers are trying to follow schools of thought on race, gender and class. Last research on electronic literature deals with the change of perception regarding the role of the hypertext's reader, who acquires an active role, becoming a user or participant, more than a passive reader. In this article the cultural agents which affect the reader will be studied to reflect the pedagogical function of hypertext fiction about gender issues.

Hypertext -the text displayed on a computer- was created by Ted Nelson and other engineers in 1965. Subsequently the development of the Apple Computer took place in 1987, the World Wide Web (in the late 1980s), Windows (1985) and Lynx (1992). Eastgate Systems was the first publisher and software company which published hypertext fiction. It was founded in 1982 and the first software for writing electronic literature was Storyspace, a hypertext system created in 1980s by Jay David Bolter and Michael Joyce. Recently, Mark Bernstein has created a personal content management system developed for Mac OS and Mac OS X to create hypertexts in 2006. Recent hypertext theoreticians have examined the qualities of hypertext following poststructuralist notions (LANDOW, 2006), (MOULTHROP, 1991), analysing the differences between printed and electronic literature (AARSETH, 1997), (YELLOWLESS, 2001), and enumerating the different genres of electronic literature, its context and preservation (HAYLES, 2008). More recent research promotes courses on electronic literature using hypertext for teaching (LANDOW, 2006) (KOSKIMAA, 2010) (BORRÀS, 2005) (PAJARES, 2001) (LÓPEZ VARELA, 2009, 2011). Other new researchers and hypertext writers explore the new territories of networked and programmable hypertext fiction such as John Cayley (2011), Loss Pequeño Glazier (2001), Alan Sondheim (2006), Brian Kim Stefans (2003), and Stephanie Strickland (2011). And others study the critical interpretation of electronic media building bridges between digital art, literature and games: Ian Bogost (2009), Wendy Hui Kyong Chun (2005, 2006), Florian Cramer (2004), Matthew Fuller, Lev Manovich and Noah Wardrip-Fruin (2008) and Matthew Kirschenbaum (2008).

In previous research the discussion on the didactic use of hypertext has been enriched by cyberfeminist theories, artworks and activism. First cyberfeminist 
writers and artists as well as researchers on cyberfeminism emphasized the importance of women in the new technologies and how virtual reality could be a space in which gender differences were blurred (HARAWAY, 1990) (STONE, 1991) (PLANT, 1998) (HAYLES, 1999). Those defenders of the "intrusion" of women in cyberspace to fight for their rights and destabilize the patriarchal system were rapidly conscious of the still precarious and exploited situation of hundreds of women working in the new technologies (Plant 1998), the elitism of women in cyberfeminist New Media art (FERNÁNDEZ, 2002) and the denigration of women's bodies in cyberspace. At the same time other writers and artists found liberation of gender boundaries on the Internet and supported the deconstruction of gender and bodies in cyberspace (BRAIDOTTI, 1996) ("E-mail Exchange with Shu Lea Cheang", CHEANG, 2000), (GOICOECHEA, 2004), (GALLOWAY, 2010).

Given the innovative character and originality of this research a mixed accurate methodology will be applied. The intersection among gender studies, electronic literature and New Media art requires an interdisciplinary study of diverse academic disciplines: cultural, gender and media studies. The main questions in this article are: 1. How feminist hypertexts can be pedagogical? And 2. How hypertextual feminist fiction can illustrate feminist theory?

On the one hand, hypertext narratives about gender issues provide the instructor and the students a series of characteristics which can improve the student's possibilities of discussions on gender issues, being short hypertext fictions they can be read and commented in class by the instructor and the students and their visual elements invite to discuss on different kinds of symbols related to gender matters. The professor can choose a corpus of electronic literature about feminism, gender and sexuality. Some electronic literary works studied in class could be: In the first place, classic works of hypertext fiction about gender such as Carolyn Guyer's Quibbling (1993) and Shelley Jackson's Patchwork Girl (1995). These hypertexts were created with the software program Storyspace and they offer the students the experience of approaching electronic literary texts which can be read following multiple paths, the concept of multilinearity can be explained through the reading of these texts as well as the rhizome theory which Guyer 
illustrates in Quibbling. The disadvantages of working with these texts is that they are in a CD format and have copyright, they are not easily found in libraries, and therefore, students would need to buy their own copies through the Eastgate Systems Publisher Website. In the second place, hypertext cyberfeminist fiction could be analysed to make students aware of the influence of cyberpunk and queer theories in illustrated hypermedia such as carrier (becoming symborg) (1999) by Melinda Rackham and Damien Everett and Francesca da Rimini's Dollspace (2001). Other electronic literary works by women authors could be studied such as: Caitlin Fisher's These Waves of Girls (Winner of the Electronic Literature Organization's Award for Fiction, 2001), M.D. Coverley's Accounts of the Glass Sky (2001), Ingrid Ankerson and Megan Sapnar's Cruising (2001), Dawn (2005) by Reiner Strasser and Alan Sondheim, Susan Gibb's Blueberries (2006) and many others. In the third place the students could learn how to use computer programs to create their own electronic literary works.

On the other hand, another way of using the new technologies for learning about gender issues is creating a Website on gender theories with hypertext. A hypertext is an open text which can be constantly rearranged and students can add opinions and comments to a debate on gender issues. Also in a hypertext format students can make comments about a particular passage of a book, write reviews of books and publish them online - in blogs or in Google books for instance-. University students can discuss about a text in class, subsequently write their comments on a website or blog about their individual readings at home and the following day a discussion on class will be more completely developed.

As an excuse for not including hypertexts in teaching it has been said that hypertexts are too difficult to be read. The origin of this way of thinking comes from the traditional idea that a text is linear and the reader is used to understand the process of reading just with an eye movement and turning over pages. Nevertheless, readers confronting a hypertext have to deal with nodes, links and paths. The way information is found on a hypertext does not follow only one direction but multiple ones. Reader's difficulties to understand hypertexts can not be avoidance to acquire knowledge because there is a high percentage of people 
who do not read printed books very often but read constantly on the computer screen, and not only for working purposes, but also to get information or to read texts which can be found online. In fact, young learners, adolescents and children have been brought up in an environment clearly influenced by the audiovisual media and the use of the new technologies. Therefore, they can find more easily than adults specific information from a website and learn new terms and theories from a hypertext format. Students are accustomed to use computers for writing, reading, exchanging information and playing. It is easier for young people to understand and read hypertexts than for the older ones, getting used to read hypertexts is a process which consists of learning new signs and types of movements. Print narrative readers are used to the eye movement of reading, following only one direction and turning pages. However, there are physical changes which seem to be unnatural for adults who have never read a hypertext or hypermedia: multimodal storytelling requires an assimilation of different environments for receiving information: written, visual and audio. Hypertexts allow readers and students to develop multiple literacies (literary, cinematic, artistic, etc). The multitasks of electronic literature works demands a capacity of memorising passages and paths to be able to move from one extract to another without getting lost. In this sense hypertext fiction is similar to video games due to the interactivity of the reader whose actions, choosing one link or another, determine the reading process. A new kind of attention is needed to understand hypertexts: "Deep, focused attention is what print readers are trained to have, but attention itself is being reshaped, becoming a mix of deep and hyper, or focused and mobilized. Elit, like Deena Larsen's Carving in Possibilities, requires, shapes, and comments on just this type of new attention (Strickland "Born Digital" n/p). George Landow considers that this kind of reading offers new educational habits which help to understand complex ideas: "Literary or humanistic assumptions about disorientation seem related to a conception of education in which students learn to deal with complex matters of interpretation" (LANDOW, 2006, p. 150).

The question of interpretation is the most interesting one with regards to gender issues. Hypertext readers can find more appealing to read on women's needs of equality, homosexual rights, and criticisms to the patriarchy consequences in our 
contemporaneous society from hypertexts which are open to be interpreted -like in postmodernist fictions in which the plot is fragmented and there is an open ending. Common characteristics of hypertext fiction: multimodality, collaboration and open access create the appropriate environment for defending men's, women's and LGBTI (Lesbians, Gays, Bisexuals, Transsexuals and Intersexuals) rights like in Francesca da Rimini's Dollspace (2001).

\section{What feminist hypertexts have to offer to the discipline of gender studies}

There are a series of qualities that hypertexts can provide to the study of gender theories and feminist literature. I have enumerated these characteristics in the following chart I have created as a result of my research to contrast how hypertexts can represent feminist goals. Obviously, some of the characteristics of the left column can also be found in texts, not only in hypertexts, but in the latter these qualities are more frequently found, and as a medium, it invites more collaborative and subjective narratives.

\begin{tabular}{|c|c|}
\hline Feminist texts & Feminist hypertexts \\
\hline Pages & Links and lexias \\
\hline Authorship & Collaborative authorship \\
\hline One voice & Multivocality \\
\hline The self $^{1}$ & Subjects-in-process \\
\hline Linearity $^{\text {Multilinearity }}$ \\
\hline One end or multiple endings & Multiple endings or non-ending \\
\end{tabular}

\footnotetext{
${ }^{1}$ Julia Kristeva revolutioned the classic Freudian conception of the self and the distinction between consciousness and the unconscious transforming it into a gender matter. For Kristeva, the self is a subject of enunciation-a speaker who can use the pronoun ' $l$ '. The masculine symbolic and the feminine semiotic are equally essential to the speaking subject, whatever this individual's socially assigned gender may be. It is not possible, then, to be masculine "self" or unsulliedly feminine "self". Every subject of enunciation-every self-amalgamates masculine and feminine discursive modalities. The self is object of discussion in feminist hypertext fiction: multiple identities, the reaffirmation of the self, the disappearance of the memory of the self, etc.

${ }_{2}$ Hypertexts do not have a clear ending, they imply a circular reading process, the work is always increasing and changing. Some hypertexts are similar to videogames like Kate Pullinger's
} 


\begin{tabular}{|c|c|}
\hline Traditional or fragmented narratives & Fragmented narratives \\
\hline Discourse & Dialogue \\
\hline Fixed medium & Textual Openness \\
\hline Coherence & Association \\
\hline Sections & Intersections/Connections \\
\hline Unified-subjectivity and subjectivities $^{3}$ & Subjectivities and intersubjectivities \\
\hline Intertextuality & Hypertextual intertextuality \\
\hline Hierarchical structures & Non-hierarchical and rhizomatic \\
& structures \\
\hline Kathartic effect & Neo-kathartic effect \\
\hline Publishing & Open publishing \\
\hline
\end{tabular}

Inanimate Alice (2005-2008) and the user can find different adventures depending on the spaces and objects he/she chooses. This way, the fiction permits many possible multistories and endings. In a hypertext fiction like Francesca da Rimini's Dollspace (2001) when the reader has gone through several poems, images and stories there is a moment in which he/she finds a lexia (or webpage) where there are several links, one drives to the beginning, others to middle sections of the narrative and other to the last sections of the story. Also, in Susan Gibb's Blueberries (2009) there are multiple stories within the same one and multiple endings, however in any of these paths the reader will always find a middle part in which he/she can choose among the links called: "present, past and future" and be driven to different confessions of the speaker. This middle from which the reader can have access to other parts of the fiction can be called the "milieu" if it is associated to the rhizome theory. The philosophy of the rhizome was developed by Gilles Deleuze and Félix Guattari in A Thousand Plateaus (1980). Deleuze and Guattari explained the philosophical concept of the rizhome as follows: "[The rhizome] is composed not of units but of dimensions, or rather directions in motion. It has neither beginning nor end, but always a middle (milieu) from which it grows and which it overspills" (Deleuze and Guattari 23). George Landow supports the idea that a hypertext like a rhizome "has multiple entryways and exits, embodies something closer to anarchy than to hierarchy, and it connects any point to any other point" (Landow Hypertext 3.0. 61-62).

${ }^{3}$ In postmodernist literature and philosophy the idea of a decentered subjectivity was born, it emerged during the late nineteenth and early twentieth centuries in the writings of a variety of thinkers including William James (1842-1910), Sigmund Freud (1856-1939), and the critical theorists Max Horkheimer (1895-1973) and Theodor Adorno (1903-1969). The early modern conception of a centered subjectivity came from the Cartesian dualism in which the mind and its thinking essence were seen as functioning independently of the body and the material world (René Descartes; Discourse on Method, (1637). Postmodernist feminist literature and philosophy shows an emergency to finish with the idea of the unified subject to admit the existence of multiple idenitities, in hypertext theory the decentering of the author makes possible the existence of subjectivities and intersubjectivities. 
In a feminist hypertext there are some crucial differences which allow readers to find multiple entrances (and exits) through links and lexias. Those characteristics are beneficial in a gender studies environment because they offer multiple voices and a decentering potential which erases hierarchies in discrepancy about gender matters or among different feminist streams. Ingrid Hoofd (2002) affirms that a hypertext "has links/trails that can work as a metaphor, and that explicitly can visualise a 'stiching together' of what has been 'ruptured in societal discourses'" (Hoofd $n / p)$. In texts about society's restrictions on gender the form of a hypertext illustrates how the self, as well as the hypertext, is fragmented and the reader needs to 'stitch together' the metaphors to understand the content. The multilinear nature of hypertext allows layering of different voices and perspectives within one text. The importance of biographies and multiplicity of voices are not exclusive notions of hypertext, modernist and postmodernist fiction and non fiction already exemplified multivocality. Mikhail Bakhtin writes about the dialogic, polyphonic, multivocal novel, which he claims "is constructed not as the whole of a single consciousness, absorbing other consciousnesses as objects into itself, but as a whole formed by the interaction of several consciousnesses, none of which entirely becomes an object for the other" (BAKHTIN, p. 18, quoted in LANDOW, 2006, p. 56). Bakhtin considers the Dostoevskian novel as a polyphonic literary form, a hypertextual fiction in which voices take the form of lexias.

The multivocal novel is not something unique to hypertexts. In the last few decades feminists have written multivocal novels like Toni Morrison's Beloved (1987). A high percentage of feminist fiction and non fiction is based on women testimonies: Alice Walker's The Color Purple (1982), Margaret Atwood's Surfacing (1972), Lee Maracle's I Am Woman (1988), etc. Nevertheless, feminist fiction in a hypertext counts with a series of elements which can illustrate equality messages in an innovative and powerful way: visual modes, images in motion and flashing graphics. Multiple endings in hypertext fiction invite the reader's reflection and can also be used as a feminist strategy to make the reader wonder how personal experiences are influenced by gender oppression, or on the contrary, by gender subversion and freedom to choose a determinate kind of behavior and lifestyle. Besides, hypertext feminist fictions are written in a global environment and use a 
discourse which corresponds to the present day gender and sexual issues: racism, femicide, immigrant women's issues, AIDS, transgender people issues, etc. Stephanie Strickland, poet of electronic poetry and theorist of hypertext fiction praises electronic literature for offering media adapted to present day world: "E-lit is the mode of literature appropriate to new social conditions" (STRICKLAND, $2011, \mathrm{n} / \mathrm{p})$.

Collaborative authorship is being used more in hypertexts than in linear or/and printed texts and it benefits authors specially when a subject needs to be reinforced by multiple points of view to accomplish credibility, this is the case of gender matters which are treated by not only Western feminist authors but also by other women from different ethnic origins and also men and transgendered people, like in Francesca da Rimini's Dollspace. In Hypertext 3.0 George Landow claims that in a hypertextual environment, the figure of the author actually comes closer to the figure of the reader, because the reader becomes a more active coproducer of the text. Landow shows how both Roland Barthes and Michel Foucault problematise the modernist concept of the author. This concept closes off the text and plays down collaboration. Foucault, who coins the term 'author-function' to show how this concept is actually a mechanism of power in a (group of) text(s), argues that an author/writer is not just somebody who writes, but that the concept is highly socially and historically constructed. This author-function economically and culturally both exerts power and allows for empowerment. Foucault's critique allows Landow to theorise a much more multiple concept of the author, and this in turn dramatically changes power structures in academic scholarship, allowing for explicit collaboration. Furthermore, since in hypertext the boundaries between inside and outside the text get more blurred, which Landow also relates with Derrida's idea of decentralising and to his notion of intertextuality of a text, 'the' author automatically gets moved away from its central position in the text/the field of (academic) writings, to become (just) a 'node in an information network' (Landow 129).From a feminist perspective, Ingrid Hoofd sees these features as positive for all kinds of feminisms. The concept of the decentered self/author, together with the proliferance of the information technologies, can allow feminist theory to take up a more fruitful hybrid notion of (nomadic) subjectivity. 
Furthermore, the potential lessening of hierarchies between academic texts and the foregrounding of collaboration, that together with the hybrid space of the Internet tends to blur the distinction between the public and the private, are of great value to construct a more inclusive account of feminisms (HOOFD, 2002, $n / p)$.

\section{Feminist hypertexts and intersubjectivity}

Feminists have always been interested in making public what is private to transform the idea that "a personal case", for example a victim of gender violence, cannot be considered an exceptional case when it is statistically found that it is a common tendency. At the beginning, laws to defend women who suffered domestic violence were addressed against husbands. Later, feminists showed that not only housewives but also many other women needed to be protected from aggressions by boyfriends or other male partners. Gender violence studies were developed during the second wave of feminism (from 60 s to 80 s) to determine that private personal cases should be publicly spoken to protect victims and educate the population that violent acts were not only physical ones.

Testimonies are very common in contemporary feminist writings. According to Laura L. Sullivan the biographical elements in feminist fictions have the aim to reveal the relationship between the individual self and society and history (Sullivan 31). bell hooks, author of Feminism is for Everybody (1996) wrote in her memoir, Bone Black: Memories of Girlhood (1997) stories of black girls affirming that "not enough is known about the experience of black girls in our society" (xii quoted in Sullivan 31). Feminist autobiographies hold onto the reality of oppression and challenge the unified, rational subject of humanist tradition. Feminists reject essentialist and universalist ideas of the "self" and raise the voices of the "subjectin-process" 4 , the identity defined by the social and historical experiences. What happens then when one subjective state is shared by two or more individuals? In hypertext fiction a phenomenon is personally experienced (subjectively) but by

\footnotetext{
4 ."Subject-in-process" is a term coined by Julia Kristeva (1984), it means that the individual subjectivity is in a continuous process of differentiation and there is not a unified self.
} 
more than one subject -the writers, the artists, the multinarrators and the users-, the same emotions can be shared, even in real time in some multimedia projects where readers can collaborate writing in blogs or writing comments. The creation of collaborative hypertexts implies constant changes in which the different personalities of writers are reflected. Also, the fact that a hypertext -even if it is not open to the reader's participation adding notes-is an interactive and multimodal text requires rereadings and one reading can give new information which can change the perspective that the reader had at the beginning of the same story. The experience of "the other" -the protagonist- is lived by the reader whose actions (choosing one path or another, clicking on symbols, drawing, writing or moving the mouse) intervene in the storytelling. The produced effect can be called "hypertextual intersubjectivity".

Intersubjectivity represents a comprehensive emotional, intentional/motivational, reflective, and behavioral experience of the other. It emerges from shared emotions (attunement), joint attention and awareness, and congruent intentions (LOPEZVARELA AZCÁRATE, 2010, p. 126)

The fragmentation of feminist hypertext fictions counters the idea that texts are unified and self-contained. Readers of feminist hypertexts need to read several times the hypertexts, reflect on their content and need to spend some time and even research to figure out the text's meaning, since feminist hypertexts are highly ambiguous and even contradictory there is not one single correct meaning. The gaps in the text create ambiguity and open doors for a multiplicity of meanings. Differences in interpretation are part of the process of textual reception, a process which involves the reader's own positionality as well as that of the author(s) of the text. Sullivan uses feminist hypertexts for teaching precisely because of its fragmentation and celebration of subjectivities. As she states:

Hypertext makes use of these strategies, as the text is fragmented and contains different types of information, emotional and conceptual, personal and social, historical and current, official and unofficial, rational and unconscious. These different types of information are connected in hypertext trough juxtaposition, either 
within one page, as in collage, or through linked pages, as in filmic montage (SULLIVAN, 1999, p. 36).

Generally, electronic literature exploits hypertext's intersubjectivity potencial. In a hypertext each character speaks in the first person, most of the times the speaker is unknown and he or she addresses the reader and makes rhetorical questions to induce the reader to fabricate his/her own answers. In hypermedia related to social and gender issues the reader starts exploring the hypermedia trying to guess who is speaking, what are the reasons for his/her happiness or pain, how he or she feels about the topics of the hypertext and his/her own opinion. The effect of reading a hypertext is similar to the one of attending to a meeting or debate: the individual had preconceived ideas about certain subjects and can be surprised or even change his/her own point of view after having learnt from his/her interlocutors. In hypertextual fiction many possibilities are offered to establish a dialogue among characters themselves, between reader and writer and among readers. They can choose different reading paths, chronological order, interpretations and can edit comments to the text. This dialogue substitutes the traditional discourse and is what readers and students should experience when dealing with gender isssues, in order to respect other points of view and to discover that not all individuals experience gender in the same way. Ingrid Hoofd highlights how multiple voices and narrative lines through a docuverse may make a reader aware of the fact that there is no grand narrative any more, only 'differends', and hypertext has many options of causing 'avant-garde formlessness'. And finally, hypertext often lends itself explicitly to re-reading, because it defers any final closure and can be potentially infinitely re-opened (Hoofd, "A Hypertext Poetics" n/p). A hypertext is not a fixed medium, it can be rearranged and re-opened and this permits a more flexible form for discussion.

\footnotetext{
${ }^{5}$ With the terns grand narrative and differends Ingrid Hoofd is referring to two concepts by JeanFrançois Lyotard. Grand narrative is a term he introduced in The Postmodern Condition: A Report on Knowledge (1979). According to him in the tribal times the narratives legitimated knowledge and the myths functioned as a legitimation of the existing power relations and customs. However, in modern times the citizens do not believe in grand narratives anymore. The concept of differend is explained in The Differend: Phrases in Dispute (1988) where he explains that a differend is a case of conflict between parties that cannot be equitably resolved for lack of a rule of judgement applicable to both. Therefore, Ingrid Hoofd uses Lyotard terms to explain that in hypertext like in postmodernist literature there are no longer absolute and universal rules or conditions that are valid for all statements.
} 


\section{Hypertexts, Intertextuality, and Gender Studies}

Hypertexts also offer advantages on the transmission of intertextuality: "Hypertext, which is fundamentally an intertextual system, has the capacity to emphasize intertextuality in a way that pagebound text in books cannot" (Landow 35). In hypertext fiction allusions to other authors, quotations or cultural signs can be found just clicking on a link. The link moves straightforward to the reference and the reader will read the reference faster than reading on a printed book, where he has to turn many pages to find the reference.

Another element which increases the relevance of intertextuality are visual modes, for instance, in Dollspace we can find illustrations from Marquis de Sade's books. These famous illustrations help the reader to associate what de Sade's figure implies: sadism, libertine lifestyle, rape, misogyny, sodomy, torture and blasphemy against the Catholic Church. Marquis de Sade is a cultural imagotype of a libertine for some, although a misogynist for others. Angela Carter and Susan Sontag considered him a "moral pornographer" while Andrea Dworkin saw him as a "woman-hating pornographer". Visual modes activate the associations on the reader's perception activating intertextuality in simultaneous ways, since within it we can find many references to other texts in different modes: written, visual and audio.

Intertextuality permits to open different feminist approaches in the same text without giving more importance to one or another because it is the reader who chooses which extract is going to be read before or after. In Shu Lea Cheang's Brandon we find biographies of transsexuals and intersexuals. But queer theory is not the only important approach in this hypermedia work. There are also parallel feminisms: women of color feminism, cyberfeminism and sex positive feminism ${ }^{6}$.

\footnotetext{
${ }^{6}$ Sex positive feminism is a movement that was formed in the early 1980 s as a response to efforts by anti-pornography feminists such as Catharine MacKinnon, Andrea Dworkin, and Dorchen Leidholt to fight against pornography considering it an element whish increased women's oppression. This period of intense debate between anti pornography and sex positive feminists is known as the Feminist Sex Wars. Sex positive feminists authors included Camille Paglia, Patrick Califia, Gayle Rubin, etc. Sex-positive feminism centers on the idea that sexual freedom is an
} 
In the case of hypertexts adapted to study novels in a literature class we can find, as George Landow states, a more "explicit" reading: "A hypertext presentation of the novel [James Joyce's Ulysses] links this section not only to the kinds of materials mentioned but also to other works in Joyce's career" (35). Using hypertext for studying literature, as George Landow and Susana Pajares suggest, can be very practical to analyze complex texts such as Ulysses and The Portrait of the Artist as a Young Man by James Joyce, which are among the first hypertexts created and need a medium to project intertextual links. Lecturing on modernist literature and on writers such as Henry James or Virginia Woolf, whose works are objects of analysis, it would be interesting to have all the information organized in different lexias: stream of consciousness extracts in one lexia, intertextuality in other, autobiographical references in another, etc.

Working with hypertexts when we deal with gender matters can be really useful because it is essential to have references of other arguments when we are facing, for example, a complex philosophical text like Gender Trouble by Judith Butler, which requires an educated reader to understand previous theories from Simone de Beauvoir or Jacques Lacan. In a hypertext structure the reader can find all the needed information to understand each chapter of a complex work of non-fiction or fiction.

One of the main difficulties of working with feminism is the difference of opinions and the existence of a large variety of "feminisms". Ingrid Hoofd considers that especially queer theory and Black feminism have produced a substantial amount of critiques on the Western, white, middle-class and heterosexist hegemonic account of feminist theory as described in many feminist overview books and articles, also pointing out how these knowledge formations relate to the sociocultural material power of the West (HOOFD, 2002, n/p). Hypertext might be a tool in which there are no hierarchies among some feminisms and others, Black and queer theory would not be put in mere footnotes next to white hegemonic

essential component of women's freedom. As such, sex-positive feminists oppose legal or social efforts to control sexual activities between consenting adults, whether these efforts are initiated by the government, other feminists, opponents of feminism, or any other institution (Tandon 67). 
feminism. In a hypertext all feminist theories can be at the same level of importance because there is not an order of chapters like in a printed book, the reader chooses the theories to be learnt.

\section{The rhizomatic structure of hypertext}

Another important feature of hypertext which benefits feminist writings is its rhizomatic structure. In a hypertext the important information is always in the middle, because there is no beginning nor ending (or not only one beginning but many and many endings, as I prefer to understand). According to Landow, Deleuze and Guattari's explanation of a plateau accurately describes the way both individual lexias and clusters of them participate in the web: "A plateau is always in the middle, not at the beginning or the end. A rhizome is made of plateaus" (2006, p. 21). Carolyn Guyer, professor and author of the classical feminist hypertext fiction, Quibbling, has stated that when she encountered A Thousand Plateaus, she found in Deleuze and Guattari's ideas what she was looking for. In Quibbling, she rejects the Aristotelian notions of plot in her hyperfiction and represents the nomadic thought instead. Guyer considers that the rhizomatic structure of Quibbling, her hypertext fiction, has a feminine component. Guyer is interested on the interactivity of the reader, qualitity which contrasts with the attentive and responsive reader of non-interactive narratives, and this interactive element is what Guyer associates with feminist writing.

Quibbling makes us wonder whether hypertext fiction is in some way a feminist sort of writing, the electronic embodiment of that l'écriture feminine for which Hélène Cixous called several decades ago [...] Guyer believes that hypertext -an intrinsically collaborative form as she employs it- speaks to the needs and experience of women (LANDOW, 2006, p. 243)

According to Landow, the self of the hypertext author takes the form of a decentered network of codes that serves as a node within another centerless network (2006, p. 127). Feminists are interested in decentering authoritative discourses and that is why the use of hypertext for feminist hypertext fiction is convenient. Carolyn Guyer explains: "we have learned from our mothers, that the 
woven practice of women's intuitive attention and reasoned care is a fuller, more balanced process than simple rational linearity" (quoted in LANDOW, 2006, p. 243). According to Diane Greco, Guyer sees hypertext as the embodiment of "ostensibly female" (or perhaps, feminine) characteristics of intuition, attentiveness, and care, all of which are transmitted from one woman to another. However, it is doubtful that hypertext, or any other mode of writing, may be essentially female or feminine. An excellent writer must have both female and male ways of writing. Virginia Woolf supported the idea of the androgynous writer who escaped from female or male writing in A Room of One's Own:

Coleridge perhaps meant this when he said that a great mind is androgynous. It is when this fusion takes place that the mind is fully fertilised an uses all its faculties. Perhaps a mind that is purely masculine cannot create, any more than a mind that is purely feminine, I thought. (WOOLF, 1989, p. 23).

Anonymity can also be an advantage of hypertext writing. Ingrid Hoofds considers hypertext a genderless writing; George Landow calls this phenomenon "Erosion of the self" and "reconfiguration of the author". The rhizomatic structure visibilizes multiplicity in opposition to the unified self of the Western masculine traditions. Ingrid Hoofd claims that hypertext fiction involves "re-reading" and demands the reader a neo-kathartic effect which makes him/her aware of the existence of multiple mini-narratives and of a pleasurable coexistence of potentially contradictory points of view (HOOFD, 2002, n/p). In some hypertexts, mourning has an affirmative, a constructive value (and can thus induce a 'neo-katharsis' effect). Some feminist hypertextual narratives in which we find neo-katharsis are Shelley Jackson's Patchwork Gin, Susan Gibb's Blueberries, etc, where links do the metaphorical stitching together of what has been 'societally ruptured'. The various points of view of the characters overlap and contradict themselves. From Hoofd's point of view, this neo-kathartic effect provokes 'fragmentation' of the reader's identity, resulting in "new notions of subjectivity as hybrid instead of falsely unified (HOOFD, 2002, n/p). 


\section{Hypertexts and open-publishing}

Hypertext politics definitely benefits women, giving them the possibility to open publishing, making public works which previously could have been rejected by publishing houses because of their critical and feminist content. The introduction of a more feminist canon on teaching can also be improved by the use of hypertext, where there are no hierarchies. The Brown University Women Writers Project, for example, uses hypertext to increase the visibility of previously unknown or littlerecognized writing by women in order to provide a fuller representation of women writers before the Victorian period (SUTHERLAND, 1993, p. 53). As Diane Greco states, certainly hypertext should function as a protective enclave for women's writing, but its protective capacity should neither ghettoize the writing nor politically paralyze the writers; we must explicitly recognize that any claims to the subversive potential of hypertext must intend to subvert not particular groups or sexes, but any groups or individuals exercising power and authority over others (GRECO, 1996, n/p).

\section{Conclusion}

Digital literature can no longer be seen as a menace for reading, writing and studying literature. Nowadays, electronic literature does not imply the substitution of printed works; on the contrary, it updates some of the elements that make literature possible: distribution, publication and preservation. Jay David Bolter explained how remediation is a necessary process of refashioning one media for another and the convergence of printed and electronic literature is possible (BLUTER, 1990, p. 48).

Electronic literature publishing destabilizes the romantic and traditional ideas of the author as solitary, unique and unreachable. Most of electronic literature authors work collaboratively and go beyond literacy including media elements on their writings which demands participation from new media artists, web designers and computer scientists. Open publishing gives writers the opportunity to publish works online without the publishing houses approval. This invites unknown and 
new authors to be read by multiple kinds of readers and being introduced in a literary canon which goes beyond university curricula and best-sellers. A sign of the digital literature effect is that most scholars who study electronic literature are authors themselves, a phenomenon which is not so common in other literary disciplines and movements. Furthermore, electronic literature and New Media art professors build theories on hypertext and hypermedia based on their own artistic works and the reader's perception of them. Examples of them are: Francesca da Rimini, Carolyn Guyer, John Cayley, Loss Pequeño Glazier, etc.

New Media artists have inherited anarchic and revolutionary positions from avantgarde artists. They present works against the established system, criticize political systems, follow anti-war ideas and use techniques such as collage, assemblage, borrowing images and using parody and irony as political weapons. Both New Media artists and electronic literature writers very often use literature and art as media to denounce social injustices and to promote the need of equality and respect among individuals. Traditionally feminist works (if they were included in books about literature) were to be found at the end of the volumes, however the hypertext format permits the end of the hierarchies and creates an open environment in which gender studies are at the same level of importance than the other subjects. Not only the Websites about gender studies provide a fast, economic and flexible media for the research on gender, also creative hypertext fiction created collaboratively by women and men provide an updated interactive literature inviting to reflect on gender discrimination, people's rights, subversive sexualities and the experiences of subjects-in-process.

\section{Works Cited}

AARSETH, Espen J. Cybertext: Perspectives on Ergodic Literature. Baltimore: Johns Hopkins University Press, 1997.

ANKERSON, Ingrid and SAPNAR, Megan. Cruising. Electronic Literature Organization. 2001. Available in <http://collection.eliterature.org/1/works ankerson sapnar cruising.html>.

ATWOOD, Margaret. Surfacing. London: Toad, 2009. 
BOGOST, Ian; MONTFORT, Nick. Racing the Beam: The Atari Video Computer System. Cambridge, MA: MIT Press, 2009.

BORRÁS, Castanyer. Laura. Textualidades electrónicas: nuevos escenarios para la literatura. Barcelona: Editorial UOC, 2005.

BOUCHARDON, Serge, López-Varela Azcárate, Asunción. Loss of Grasp: MakingSense of the Digital as an Embodied Experience. In: CLC Web: Comparative Literature and Culture. 13. 3 (2011): n/p. Web. Available in: <http://docs.lib.purdue.edu/clcweb/vo I13/iss3/7/>. Acess in 31 August 2011

BOUCHARDON, Serge, LÓPEZ-VARELA AZCÁRATE, Asunción. VOLCKAERT, Vincent. Loss of Grasp. Déprise, 2010. Available in <http://lossofgrasp.com/>.

BRAIDOTTI, Rosi. Cyberfeminism with a difference. In: Women Studies Utrecht Webpage. $1996 . \quad$ Available in $<$ http://www.let.uu.nl/womens studies/rosi/cyberfem.htm>. Access in Aug. 31 2011.

BUTLER, Judith. Gender trouble: Feminism and the Subversion of Identity. London: Routledge, 2011.

CAYLEY, John. Writing on Complex Surfaces. In: Dightung Digital, n. 2, 2005. Available in <http://www.brown.edu/Research/dichtung digital/2005/2/

Cayley/index.htm>. Access in Aug. 312011.

CHEANG, Shu Lea.. Brandon, 1998. Guggenheim Museum. Available in $<$ http://brandon.guggenheim.org/>. Access in Dec. 52010.

CHUN, Wendy Hui Kyong. Control and Freedom: Power and Paranoia in the Age of Fiber Optics. Cambridge: MA: MIT Press, 2005. Print.

; Keenan, Tomas. New Media, Old Media: A History and Theory Reader. London: Routledge, 2005.

COVERLEY, M. D. Accounts of the Glass Sky. In: Electronic Literature Organization. $2001 . \quad$ Available in $<$ http://collection.eliterature.org/1/works/coverley accounts ofhe glass sky.html $>$.

CRAMER, Florian. Words Made Flesh. In: Piet Zwart Media Design, v. 2, 2004. Available in <http://www.netzliteratur.net/cramer/wordsmadefleshpdf.pdf $>$. Access in Aug. 312011.

DA RIMINI, Francesca. Dollspace. Doll Yoko Thing. 1997-2001. Available in <http://dollyoko.thing.net/>. Access in Aug. 312011. 
DELEUZE, Gilles; GUATTARI, Félix. A Thousand Plateaus. Trans. by Brian

Massumi. In:

Continuum, 2004.

Capitalism and Schizophrenia, v. 2. London and New York:

DE SADE, Marquis. Philosophy in the Boudoir: Minski the Cruel. United Kingdom:

Creation Books, 2004.

DESCARTES, Renée. Discourse on Method. Trans. Donald A. Cress. Hackett Publishing Company, 1637.

FERNÁNDEZ, María. Is Cyberfeminism Colorblind? Available in <artwomen.org>. Access in Aug. 312011.

FISKE, John. Cultural Studies and the Culture of Everyday Life. In: GROSSBERG, Lawrence, Cary Nelson. TREICHLER, Paula A. (Eds.). Cultural Studies. New York: Routledge, 1992. p. 154-65.

FISHER, Caitlin. These Waves of Girls. Electronic Literature Organization. Available in <http://www.yorku.ca/caitlin/waves/>.

FULLER, Matthew; MANOVICH, Lev; WARDRIP-FRUIN, Noah. Software Studies: A Lexicon. Cambridge MA: MIT Press, 2008.

GALLOWAY, Alex. A Report of Cyberfeminism. Available in <http://switch.sjsu.edu/v27/>. Access in Aug. 312011.

GIBB, Susan. Blueberries. susangibb.net. In: Hypercompendia Susan Gibb Blog. 2009. Available in <http://susangibb.net/blog2/wpcontent/uploadsstories/101blueberries/titlec.html>. Access in Aug. 312011.

GOICOECHEA, María. El lector en el ciberespacio: una etnografía literaria de la cibercultura. Madri: Diss, 2004.

GRECO, Diane. Female Writing. Hypertext '96: The Seventh ACM Conference on Hypertext, N.Y.: ACM, 1996. p. 88-89. Available in <www.cyberartsweb.org>. Access in Sep. 92011.

GUYER, Carolyn. Quibbling. Eastgate Systems: 1992.

HARAWAY, Donna J. Simians. Cyborgs and Women: The Reinvention of Nature. New York and London: Routledge, 1990.

HAYLES, Katherine. Electronic literature: New Horizons for the Literary. Paris: University of Notre Dame, 2008.

. Electronic literature: What is it? Electronic literature organization, 2008.

Available in <www.eliterature.org $>$. Access in Feb. 32009.

. How We Became Posthuman: Virtual Bodies in Cybernetics, Literature, 
and Informatics. Chicago: University Of Chicago Press, 1999.

HOOFD, Ingrid. A Hypertext Poetics: from Aristotle to neo-katharsis. In: CyberartsWeb, Cyberspace, Hypertext, and Critical Theory. 2002. Available in <www.cyberartsweb.org>. Access in Aug. 312011.

.Rewriting feminisms. CyberartsWeb. Cyberspace, Hypertext, and Critical Theory. Available in <www.cyberartsweb.org >. Access in Aug. 312011.

HOOKS, Bell. Feminism is for Everybody: Passionate Politics. London: Pluto Press, 2000.

. Bone Black: Memories of Girlhood. New York: Henry Holt and Co., 1997.

JACKSON, Shelley. Patchwork Girl. StorySpace. Boston: Eastgate Systems, 1995.

JOYCE, JAMES. A Portrait of the Artist as a Young Man. London and New York: Penguin Classics, 1993.

. Ulysses. London: Thames Press, The Echo Library, 2009.

KIRSCHENBAUM, Matthew G. Mechanisms: New Media and the Forensic Imagination. Boston, MA: MIT Press, 2008.

KNUDSEN, Susanne V. Intersectionality - A Theoretical Inspiration in the Analysis of Minority Cultures and Identities in Textbooks. In: Colloque lartem, p. 61-76. Available in <http://www.caen.iufm.fr/>. Access in Aug. 312011.

KOSKIMAA, Raine. Literature in Digital Culture: Pedagogical Possibilities. In: Teaching Literature at a Distance. Open, Online and Blended Learning. p. 123136. London: Continuum, 2010.

KRISTEVA, Julia. Revolution in Poetic Language. Columbia University Press, 1984. Print.

LAARSEN, Deena. Teaching the Writers Conference: Link Spot Link: Electronic Literature Made Easy. In: A Teaching Blog from the University of North Dakota Office of Instructional Development. Available in <http://teachingthursday.org/>. Access in Aug. 312011.

LANDOW, George. Hypertext 3.0: Critical Theory and New Media in an Era of Globalization. Baltimore: John Hopkins University Press, 2006.

LYOTARD, François. The Postmodern Condition: A Report on Knowledge. Minneapolis: University of Minnesota Press, 1984.

LÓPEZ-VARELA AZCÁRATE, Asunción. Exploring Intercultural Relations from the Intersubjective Perspectives Offered through Creative Art in Multimodal Formats (SIIM Research Program). In: LEONE, Massimo. (Ed.) Analisi delle culture; culture 
dell'Analisi Lexia. In: Revista di Simiotica. CIRCE - Centro Interdipartimentale di Ricerche sulla Comunicazione, Torino, 2010, p. 125-147.

; NET, Mariana. Real and Virtual Cities: Intertextual and Intermedial Mindscapes. Bucharest: Univers Enciclopedic. 2009.

GLAZIER, Loss Pequeño. Digital Poetics. The Making of E-Poetries. Tuscaloosa: University of Alabama Press, 2001.

MARACLE, Lee. I Am Woman: a Native Perspective on Sociology and Feminism. Vancouver: Raincoast Books, British Columbia, Canada, 1996.

MORRISON, Toni; BYATT, A. S. Beloved. New York: Alfred A. Knopf, 2006.

MOULTHROP, Stuart. You Say You Want a Revolution? Hypertext and the Laws of Media. In: Postmodern Culture, v. 1. n. 3, May 1991.

PAJARES Tosca, Susana. Aplicaciones del hipertexto al estudio de la literatura: "A Portrait of the Artist as a Young Man", de James Joyce. 2001. Tesis (Ph.D. in Ciências de La Información). Madri: Universidad Complutense de Madri, 2001.

PLANT, Sadie. Zeros + ones: Digital Women + the New Technoculture. New York: Harper Collins, Fourth State, 1998.

PULLINGER, Kate. Inanimate Alice. 2005-2008. Available in $<$ http://www.inanimatealice.com/>.

RACKHAM, Melinda; EVERETT, Damien. Carrier. becoming symborg. Electronic Literature Organization, $1999 . \quad$ Available in $<$ http://collection.eliterature.org/1/works/rackhameverett carrier becoming symb org.html>.

SONDHEIM, Alan. Internet Text 1994 - [Through Feb 2, 2006]. In: Electronic Literature Collection. Available in $<$ www.electronicliterature.org $>$. Access in Aug. 312011.

STONE, Sandy. Will the Real Body Please Stand Up? In: BENEDIKT, Michael. Cyberspace, First Steps. Cambridge: MA: MIT Press, 1991.

STRICKLAND, Stephanie. Born Digital. Poetry Foundation, n. 13, February 2009. Available in <http://www.poetryfoundation.org/article/182942>. Access in 31 August 2011.

STEFANS Brian Kim. Fashionable Noise: On Digital Poetics. Berkeley: Atelos, 2003.

SULLIVAN, LAURA L. Wired Women Writing: Towards a Feminist Theorization of Hypertext. In: Computers and Composition, n. 16, 1999, p. 25-54. 
SUTHERLAND, Kathryn. Challenging Assumptions: Women Writers and New Technology. In: CHERNIAK, Warren; DAVIS, Caroline; DEEGAN, Marilyn. (Eds.) The Politics of Electronic Text. London: Office for Humanities Publications, 1993.

TANDON, Neeru. Feminism. A Paradigm Shift. New Delhi: Atlantic Publishers and Editors, 2008.

WALKER, Alice. The Color Purple. New York: Harcourt, 2006.

WOOLF, Virginia. A Room of One's Own. New York: Harcourt Brace \& Co., 1989.

YELLOWLESS, Jane. The End of Books or Books Without an End? Michigan: The University of Michigan, 2001.

Texto recebido em 19/06/2012 